\title{
Isolation of extended-spectrum beta-lactamases producing strains on effluent of state hospital from Boa Vista-RR
}

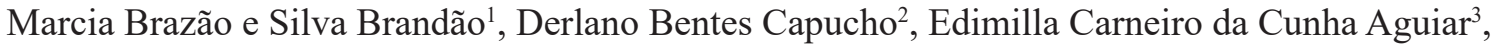 \\ Rafael Nascimento de Assis ${ }^{4}$ Fabiana Granja ${ }^{5}$
}

${ }^{1}$ Master, Professor at Federal Institute of Education, Science and Technology of Roraima, Boa Vista, RR, Brazil

${ }^{2}$ Master, Federal University of Roraima, Boa Vista, RR, Brazil. ${ }^{3}$ Graduate, Federal University of Roraima, Boa Vista, RR, Brazil

${ }^{4}$ Graduate, Federal University, Boa Vista, RR, Brazil

${ }^{5}$ Doctor, Professor at Federal University of Roraima, Boa Vista, RR, Brazil

marcia.brazao@ifrr.edu.br;dcapucho@hotmail.com; edimilla_tour@hotmail.com; rafael2013assis@gmail.com;fabi.granja@yahoo.com.br

\begin{abstract}
Resumo
As bactérias produtoras de betalactamase de espectro estendido (ESBL) estão amplamente disseminadas nos ambientes hospitalares. Os dejetos clínicos de efluentes hospitalares apresentam elevadas concentrações de bactérias com perfis de resistência a antimicrobianos e seu descarte incorreto representa risco ambiental na medida em que possibilita a disseminação. Esta pesquisa abrange a caracterização da presença de bactérias multirresistentes à antimicrobianos em cepas isoladas em efluentes hospitalares, cujos riscos associados, incluem a disseminação de microrganismos patogênicos no ambiente. Para a resolução desta pesquisa, os objetivos propostos foram: caracterização das cepas do efluente hospitalar gerado pelo Hospital Geral de Roraima (HGR) e pesquisa de genes de resistência responsáveis pela codificação de ESBL e hidrólise aos antimicrobianos da classe das cefalosporinas, penicilinas e monobactans. Foram coletadas amostras do tanque séptico do hospital no período de junho de 2014 a junho de 2016, submetidos à identificação molecular para a detecção dos genes através da reação em cadeia da polimerase (PCR). Os resultados demonstraram a presença de ESBL em todos os tanques coletados e perfil de multirresistência. Os genes de ESBL foram identificados em frequências isoladas e em combinação. Os resultados indicaram a ampla disseminação dos genes de ESBL no efluente do HGR.
\end{abstract}

Palavras-chave: Antimicrobianos; resistência; ESBL; ambiente

\begin{abstract}
The extended spectrum beta-lactamase (ESBL) producing bacteria are widespread in hospital environments. The incorrect disposal of clinical waste in hospital effluents, allows them to present high concentrations of bacteria with antimicrobial resistance profiles that present an environmental risk to the extent that they allow the dissemination. This research covers the characterization of the presence of multi-resistant antimicrobial bacteria in strains isolated from hospital effluents, whose associated risks include the spread of pathogenic microorganisms in the environment. To complete this research, the proposed objectives were: characterization of the hospital effluent strains generated by the General Hospital of Roraima (GHR) and research of the resistance genes responsible for ESBL coding and hydrolysis to the antimicrobials of the class of cephalosporins, penicillins and monobactams. Samples were collected from the hospital septic tank from June 2014 to June 2016, submitted to molecular identification for the detection of genes through the polymerase chain reaction (PCR). The results showed the presence of ESBL in all of the collected tanks and a multi-resistance profile. ESBL genes were identified on isolated frequencies and they were combined. The results indicated the widespread dissemination of the ESBL genes in the GHR effluent.
\end{abstract}




\section{INTRODUCTION}

Hospital effluents are characterized as possible vehicles for the dissemination of numerous pathogenic microorganisms, as well as large concentrations of antibiotics and drugs excreted through the urinary and fecal tracts of the patients. When they are not treated, these effluents are important contaminants of drinking water sources, both superficial and underground, and multidrug resistant strains of antibiotics can pose risks to public health if they reach the supply system (SILVA et al., 2011; VECCHIA et al. 2009).

It is a well-known fact, however, that, as a rule, these effluents are released directly into the public sewage collection system, without any type of treatment (ABREU et al., 2010).

According to the RDC No. 306, dated December 7, 2004, which addresses the technical regulation for the management of health service waste: "Liquid waste from sewage and wastewater from a health facility must be treated before they are launch in the receiving body or in the sewage collection network, whenever there is no collective sewage treatment system serving the area where the service is located "(ANVISA, 2004).

Several sources indicate that hospital effluents could contain higher concentrations of antibiotic-resistant bacteria compared to effluents from other sources, such as domestic ones. However, there is the need for more consistent results to confirm this hypothesis (REINTHALER et al, 2010). When evaluating the bacterial resistance to the drugs disposed in the effluents, ABREU et al. (2010) report that the elimination of drugs in hospitals occurs in two ways. The first by means of excretions and biological fluids, and the second by discarding the drugs consumed. Drugs that have not been used or are out of the expiration date are eliminated through the facilities' drains.

Beta-lactam antibiotics (penicillins, cephalosporins and monobactams, except carbapenems) are widely used in the treatment of bacterial infections in human medicine in the world, most of which have decreased concentration during wastewater treatment processes, but still detected in environmental samples in lower rates. Several authors, when investigating the presence of antibiotics in effluents discarded in rivers after the sewage treatment plant, detected significantly reduced concentrations of antibiotics (WATKINSON, A. et al., 2007, GULKOWSKA, A. et al., 2008, HENDRICKS, R.; POOL, E.J., 2012). Prolonged sludge retention time and hydraulic retention time during wastewater treatment will facilitate antibiotic removal by adsorption and biodegradation (NNADOZIE, C. F.; KUMARI, S.; BUX, F., 2017). The presence of ESBL-encoding genes in bacteria that colonize effluents remains poorly studied, especially in Brazil. Most of the studies are concentrated in clinical isolates (TACÃO et al, 2014)

Despite the fact that hospital effluents normally comprise less than $2 \%$ of the raw sewage effluent for treatment plants, hospitals are the main source of antibiotics in the cephalosporin group in wastewater. Preliminary disinfection of the hospital effluent to entering the sewage treatment system could minimize the spread of antibiotic-resistant bacteria to the environment. These bacteria can be displaced from the sewage to their surroundings or directly into bodies of water, which are receptors of the sewage treatment system of the effluents. This represents a risk to public health, which requires evaluation and future control (KORZENIEWSKA and HARNISZ, 2013, GUSATTI et al, 2009).

Among the several mechanisms of resistance to antibiotics, one of the most important is the production of enzymes that have the property of inactivating antimicrobials (CARMO et al., 2012).

The main one is called extended spectrum betalactamase (ESBLs), which degrade beta-lactam antibiotics. To date, more than 430 ESBLs have been characterized, many of them with descriptions in Brazil (MUNIER et al, 2010; SILVA; LINCOPAN, 2012).

Over the years and with the progressive use of beta-lactam antimicrobials, the genes responsible for assigning this enzymatic characteristic have undergone mutations that have led to the emergence of different "types" of Betalactamases, the most common being those encoded by TEM genes (Temoniera, name of the patient in which was identified for the first time) and SHV (variable Sulfhydril, chemical characteristic of the gene) that have a broad spectrum of activity, since they induce resistance to important antibiotics of different generations, therefore called Extended Spectrum Betalactamases - ESBLs. Until the early 20th century, most reports of the presence of extended-spectrum betalactamases were due to the mutation of the TEM and SHV enzymes and were described as cross-infections in hospital patients (LEISTNER et al, 2013). 
In the last 15 years, TEM and SHV genes have been replaced predominantly in the enterobacteria by the CTX-M genes and are no longer exclusively medical and have also been found in community infections (LIVERMORE et al., 2012; OVERDEVEST et al, 2011 , PATTANI et al., 2008). The CTX-M type are the most prevalent ESBL worldwide, this success is due of the combination of various factors including efficient capture and dispersal of gene by mobile genetic elements (CANTÓN, R.; COQUE, T. M, 2006; D'ANDREA, M. M. et al., 2013).

Currently, other important gens that produce beta-lactamase have been already outlined and described, such as VEB, PER, BEL-1, BES-1, SFO-1, TLA and IBC types. But they don't have a broad distribution such as the previously mentioned types TEM, SHV and CTX (LIVERMORE et al, 2012).

Studies to elucidate the biodiversity and prevalence of ESBL-producing bacteria in hospital effluents in the North of Brazil are scarce. If concentrations of these strains are high, the hospital effluents, municipal sewage, and sewage treatment plants can become reservoirs for the selection of resistant bacteria. The monitoring of this occurrence contributes substantially to delineate the magnitude of the problem and to suggest appropriate containment measures (CARMO et al., 2012; PRADO et al., 2008; SILVA; LINCOPAN, 2012).

The objective of this study is the detection and identification of the resistance genes profile related to the production of ESBLs in the General Hospital of Roraima effluent.

\section{MATERIALS AND METHODS}

\section{Study Area: General Hospital of Roraima - GHR}

The General Hospital of Roraima (Figure 1), which is part of the state public health network, is the only General Hospital reference for the entire State of Roraima, in which the population is approximately of 450,479 habitants, with $65 \%$ living in the capital, Boa Vista city. It has 333 beds, divided in five blocks, three intensive care units, a trauma sector and an emergency room unit (first aid service). The operational capacity of the hospital is approximately 13,500 patients per month (RORAIMA, 2013).

The liquid effluents generated by the GHR, according to the Waste Management Plan of this hospital, are discharged into six septic tanks that converge to a big tank and the waste is sent to the sewage treatment plant of the municipality of Boa Vista, where they are treated by the natural stabilization process (RORAIMA, 2013).

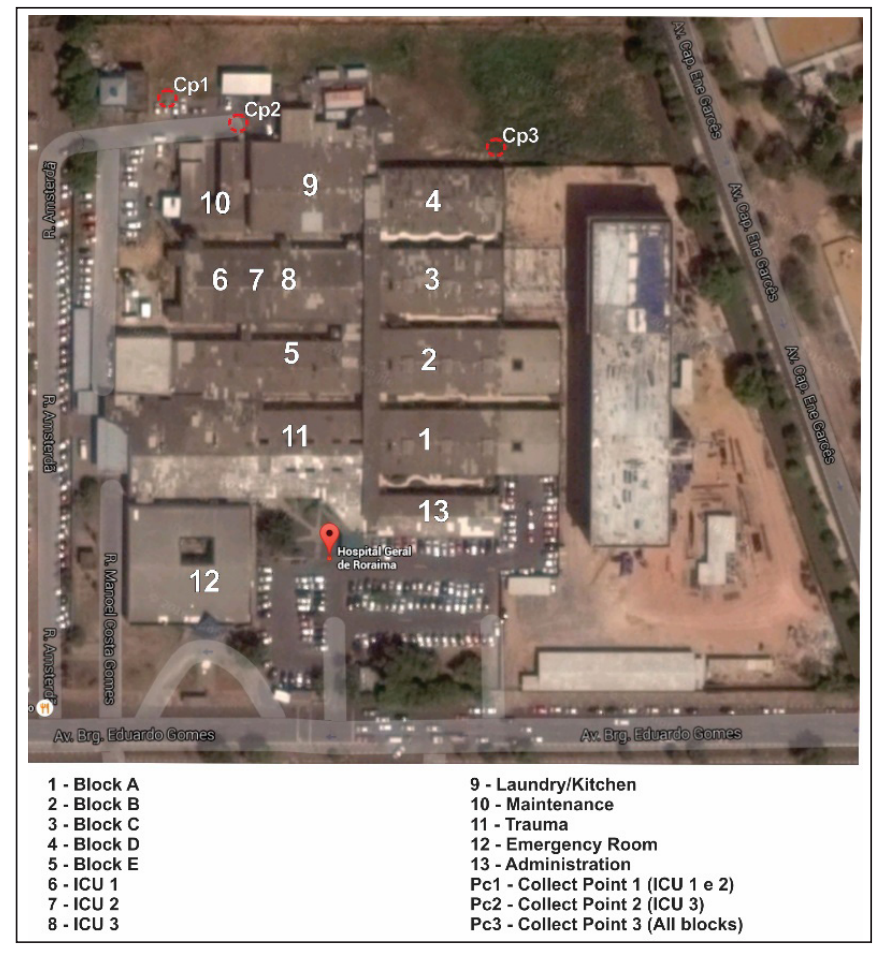

Figure 1 - Distribution of the Blocks and Wards in the General Hospital of Roraima 


\section{Collect from the Medical Effluent}

The samples were collected in March 2016, during a raining season in Roraima. For the collection of septic tanks, 3 tanks (ICU 3, ICU 1 and 2 and an access tank to the hospital blocks) were chosen. The points sampled correspond to a raw effluent without treatment. The sealing covers that correspond to the wastewater collection tanks of the ICUs were damaged. On the way to the dump tank of the blocks, an open tank was found, where the hospital employees would perform an exhaustion of the tank (Figure $2 \mathrm{~A}$ to $\mathrm{D}$ ).

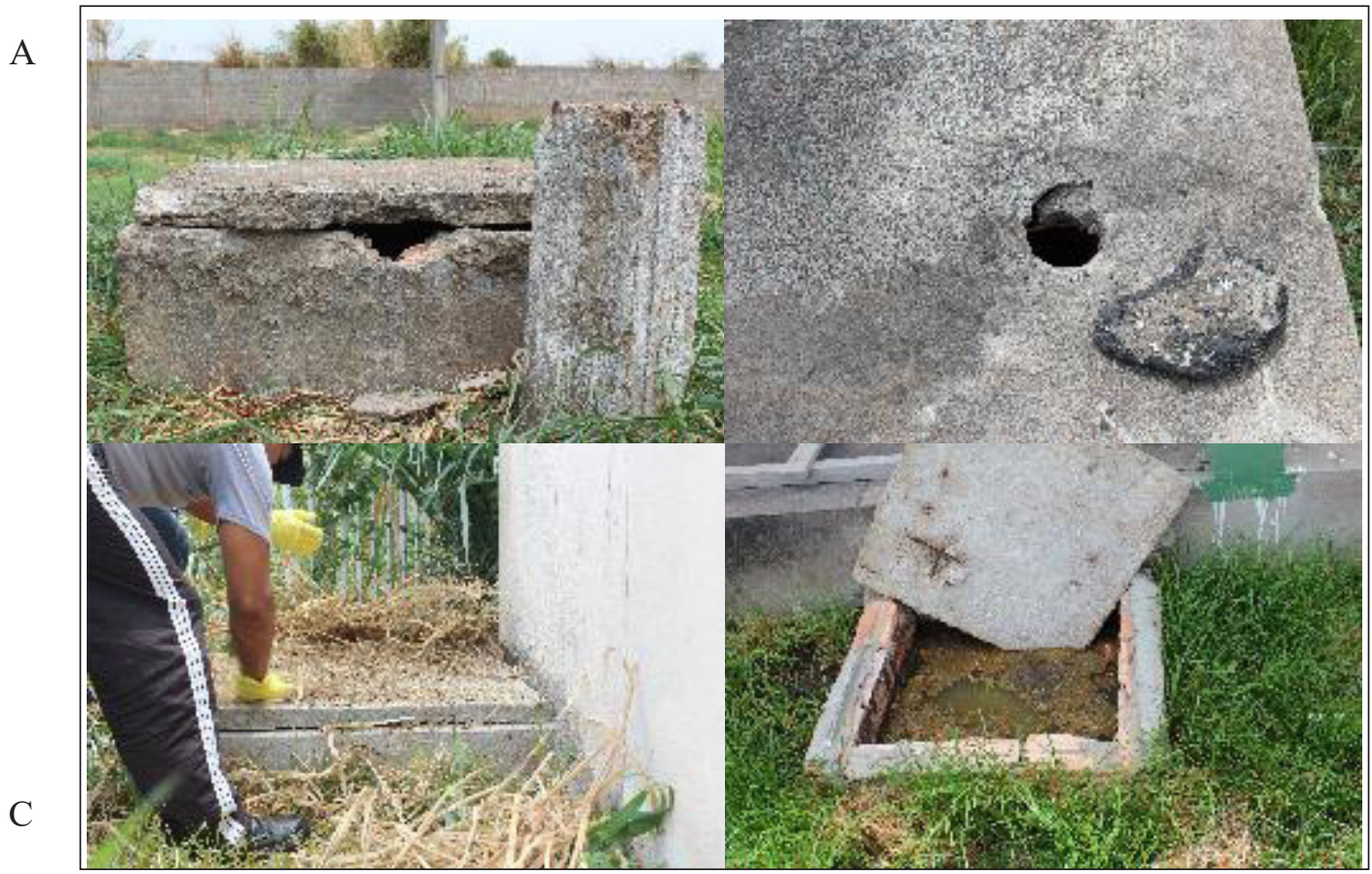

Figure 2 - Points of effluent collection at the General Hospital of Roraima - GHR

A= Collect Point 1 (ICU 1) B= Collect Point 2 (ICU 2 and 3) Collect Point 3 (All Blocks) D= Effluent passageway requiring depletion.

For the collection, sterilized polypropylene conical tubes were used in a depth of $30 \mathrm{~cm}$ and take $15 \mathrm{ml}$ of the effluent. The collection procedures occurred according to the protocol established by the Brazilian Association of Technical Norms - NBR 9897, which establishes the sampling planning of liquid effluents and receptor bodies.

\section{SAMPLE PROCESSING}

The collected samples were diluted in a saline solution with a 1:10 ratio and inoculated on McConkey Agar striation technique (HIMEDIA) and incubated aerobically at $36^{\circ} \mathrm{C}$ in a bacteriological incubator for 18 to 24 hours. Posterior phenotypic identification with the following means: Triple Sugar Iron Agar, Simmons Citrate, SIM (association of tests of the presence of Indol + Motility test), Lysine Iron Agar, Malonate, Decarboxylation of the amino acids Ornithine and Arginine and Test of the presence of the enzyme Phenylalanine Deaminase. ESBL Sensitivity and Research Test

Together with the gender/species identification, the ESBL research was performed, using the plate diffusion technique. A suspension of the bacterium under test was adjusted to the standard of 0.5 on the McFarland scale on the plate surface of Agar Muller Hinton (Oxoid), with a thickness of $4 \mathrm{~mm}$. Subsequently, the amoxicillin/clavulanic acid (Oxoid) disc was added to the center of the plaque and, around the surface, the antimicrobial markers were strategically positioned from the central disc at $20 \mathrm{~mm}$ from center to center

The antimicrobials were: aztreonam, cefotaxime, ceftazidime and cefepime. After the incubation of the plate for 18 to 20 hours at $35^{\circ} \mathrm{C}$, the presence of a halo distortion (phantom zone) was observed between the disc containing the clavulanic acid and the discs positioned around it. The presence of 
this zone positively characterized the strain for ESBL. Amikacin, ampicillin + sulbactam, ampicillin, aztreonam, cephalothin, ceftazidime, ceftriaxone, cefotaxime, cefoxitin, cefepime, chloramphenicol, gentamicin, imipenem, levofloxacin, piperacillin + tazobactam, sulfamethoxazole-trimethoprim, and tetracycline were also available on the plate.

The techniques described for cultivation and biochemical identification were developed according to the protocol of the National Agency of Sanitary Surveillance (BRASIL, 2007). The ESBL screening and confirmation tests followed the methodology proposed by CLSI in document M100-S22 (CLSI, 2012).

\section{EXTRACTION OF THE BACTERIAL DNA}

The DNA extraction was performed using the thermal shock methodology developed by Chapman et al. (2001). The technique consists in the inoculation of previously isolated Colonies in a McConkey agar in $5 \mathrm{ml}$ of Luria broth (Oxoid) at $35^{\circ} \mathrm{C}$ for $18 / 24$ hours. After this period the broth was transferred to a sterile $1.5 \mathrm{ml}$ polypropylene tube and centrifuged at $6.000 \mathrm{RPM}$ for 10 minutes, the supernatant discarded and the pellet resuspended in $400 \mu$ of ultrapure water and heated to boiling temperature for 10 minutes. The tubes were immediately frozen at $-80^{\circ} \mathrm{C}$ and thawed only for use in the PCR technique.

\section{AMPLIFICATION OF ENCODING ESBL GENES}

For the quality control of the samples, were used strains of the American Type Culture Collections: Escherichia Coli ATCC 25922 (Non ESBL) and Klebsiella pneumoniae ATCC 700603 (positive ESBL).

Amplification of the SHV, CTX-M, AND TEM resistance genes by PCR was performed using the initiators, thermal conditions and reagent concentration described by Ferreira et al. (2011) as shown on table 1 . A final reaction volume of $25 \mu 1$ containing $\mathrm{MgCl} 2(1.5 \mu \mathrm{M}), 1 \mathrm{x}$ buffer, dNTP $(0.2 \mathrm{mM})$, Taq DNA Polymerase (1U), Initiators (25pmol), $5 \mu 1$ of DNA mold and ultrapure water. All reagents used came from Ludwig Biotec. The technique was performed at the Laboratory of Molecular Biology of the Center for Biodiversity Studies - CBio of the Federal University of Roraima with the Peltier-Based Thermal Cycler.

Table 1 - Oligonucleotide initiators used for the research of resistance genes and their molecular weight and PCR conditions for their amplification.

\begin{tabular}{|c|c|c|c|}
\hline Gene & Initiators $\left(5^{\prime}-3^{\prime}\right)$ & Amplification Conditions & $\begin{array}{l}\text { Size } \\
(\mathrm{pb})\end{array}$ \\
\hline CTX-M & $\begin{array}{l}\text { F ATGTGCAGYACCAGTAARGT } \\
\text { R CTGACAGTTACCAATGCTTA }\end{array}$ & $\begin{array}{c}1 \text { Cycle of } 7 \mathrm{~min} \text {. at } 94^{\circ} \mathrm{C} \\
35 \text { cycles of } 50 \mathrm{sec} \text { at } 94^{\circ} \mathrm{C} ; \\
40 \mathrm{sec} \text { at } 50^{\circ} \mathrm{C} ; \\
1 \mathrm{~min} \text { at } 72^{\circ} \mathrm{C} ; \\
1 \text { Cycle of } 5 \mathrm{~min} \text { at } 72^{\circ} \mathrm{C}\end{array}$ & 593 \\
\hline TEM & $\begin{array}{l}\text { F ATGAGTATTCAACATTTCCG } \\
\text { R CTGACAGTTACCAATGCTTA }\end{array}$ & \multirow{2}{*}{$\begin{array}{c}1 \text { Cycle of } 5 \mathrm{~min} \text {. at } 96^{\circ} \mathrm{C} \\
35 \text { cycles of } 1 \mathrm{~min} \text { at } 96^{\circ} \mathrm{C} ; \\
1 \mathrm{~min} \text { at } 60^{\circ} \mathrm{C} ; \\
1 \mathrm{~min} \text { at } 72^{\circ} \mathrm{C} ; \\
1 \text { Cycle of } 10 \mathrm{~min} \text { at } 72^{\circ} \mathrm{C}\end{array}$} & 867 \\
\hline SHV & $\begin{array}{c}\text { F GGTTATGCGTTATATTCGCC } \\
\text { R TTAGCGTTGCCAGTGCTC }\end{array}$ & & 867 \\
\hline
\end{tabular}

Source: FERREIRA et al., $2011 \mathrm{~F}=$ Foward $\mathrm{R}=$ Reverse.

The amplified products were submitted to a agarose gel electrophoresis reaction with a concentration of $1,5 \%$ and added $0.7 \mu 1$ of the Blue Green Loading Dye fluorescent of high sensitivity (LGC biotechnology) and loaded with $2 \mu 1$ of Bromophenol Blue $(0.25 \%)$, sucrose $(10 \%)$ and $5 \mu 1$ of each sample submitted to the amplification. 


\section{RESULTS AND DISCUSSION}

Through an analysis of the bacteriological profile of the effluent in the three septic tanks collected, it was possible to identify 10 negative Gram strains, of which $40 \%$ (4) were Klebsiella sp., 40\% (4) Pseudomonas sp., and E. coli and Citrobacter freundii presented 10\% (1). The detection events per tank are shown in Table 2.

Table 2 - Distribution of the species identified according to the effluent collection point.

\begin{tabular}{c|c}
\hline Collection Point & Gender/Species \\
\hline \multirow{2}{*}{ Cp1 } & Klebsiella oxytoca \\
\cline { 2 - 2 } & Escherichia coli \\
\hline \multirow{2}{*}{ Cp2 } & Pseudomonas spp. \\
\cline { 2 - 2 } & Pseudomonas spp. \\
\cline { 2 - 2 } & Klebsiella spp. \\
\hline \multirow{2}{*}{ Cp3 } & Pseudomonas spp. \\
\cline { 2 - 2 } & Citrobacter freundii \\
\cline { 2 - 2 } & Klebsiella oxytoca \\
\cline { 2 - 2 } & Klebsiella oxytoca \\
\hline
\end{tabular}

$\mathrm{Cp} 1=$ Collection Point $1 \mathrm{Cp} 2=$ Collection Point $2 \mathrm{Cp} 3=$ Collection Point 3

Regarding the distribution of the isolates per collection point/septic tank, point 1 (ICU 1 and 2 ) and point 2 presented $30 \%$ of the detections and point 3 (correspondent to all hospital blocks) $40 \%$ of the strains.

When delineating the profile of positive ESBL strains in effluents from a hospital source, Prado et al. (2008) describe in their study that K. pneumoniae strains were detected in all samples analyzed, representing $46.5 \%$ of the total isolated strains.

The phenotypic characterization of ESBL confirmed the hydrolysis of cephalosporins from the first to the fourth generation, and the resistance profile analysis presented a $100 \%$ resistance measure to all cephalosporins tested, and 90\% to ampicillin + sulbactam, ampicillin, sulfatrimethropim and aztreonam. Graph 1 represents the complete antimicrobial resistance profile.

It is important to observe the $30 \%$ resistance frequency ratio to levofloxacin, since the class of quinolones is described as non-beta-lactam antimicrobials, but they are co-resistant in infections caused by ESBLs, a fact evidenced by a study performed by Wani et al. (2010) in the detection of ESBL in a tertiary hospital where strains showed $100 \%$ resistance to levofloxacin and moxifloxacin followed by figures of $96,2 \%$ and $93,1 \%$ to ofloxacin and ciprofloxacin, respectively.

When we performed the classification of antimicrobial resistance through isolated microorganism, it was detected that strains of Klebsiella sp. were the ones who presented the highest resistance rate (42\%), followed by $30 \%$ of Pseudomonas $s p ., 17 \%$ in E. coli and $11 \%$ in Citrobacter freundii. 


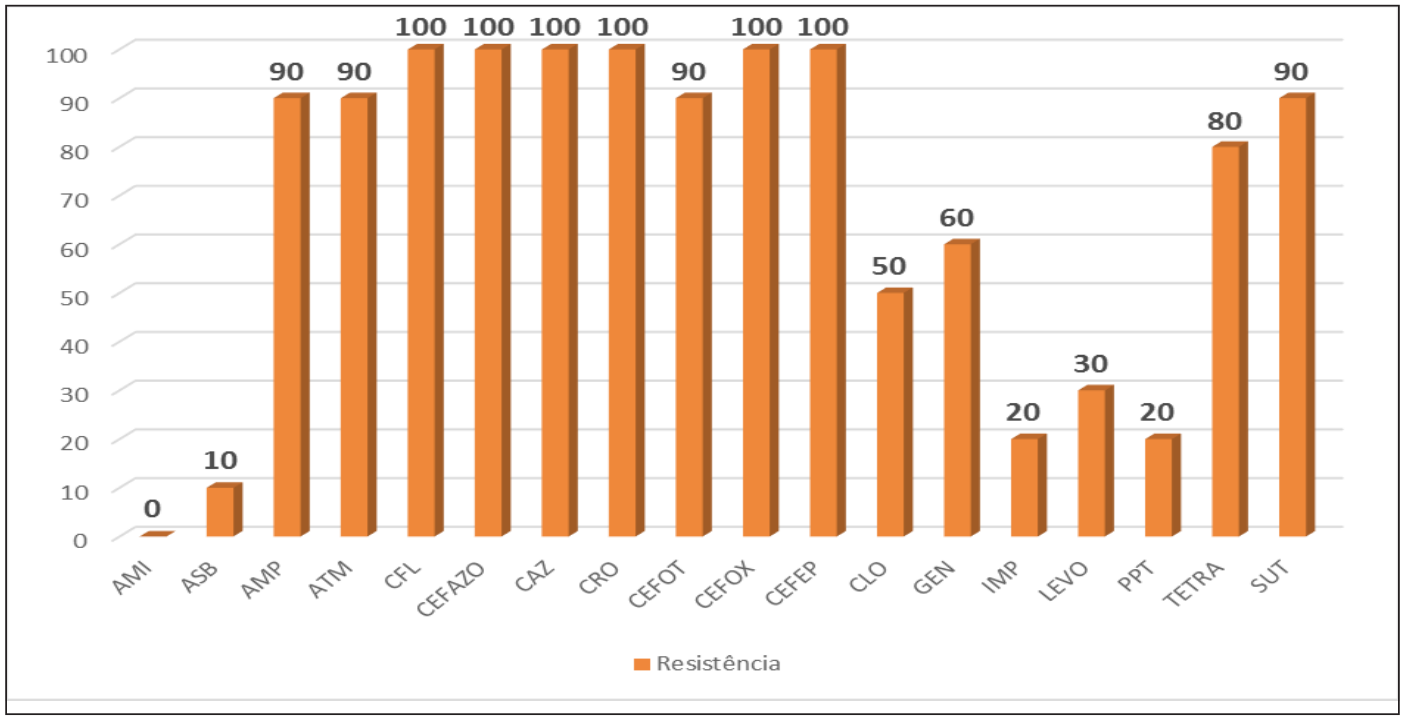

Graph 1- Antimicrobial resistance profile of ESBL positive effluent strains

Legend - AMI: Amikacin ASB: Ampicillin/Sulbactam AMP: Ampicillin ATM: Aztreonam CFL: Cephalexin CEFAZO: Cefazoline CAZ: Ceftadizime CRO: Ceftriaxone CEFT: Cefotaxime CEFOX: Cefoxitin CEFEP: Cefepime CLO: Chloramphenicol GEN: Gentamicin IMP: Imipenem LEVO: Levfloxacin PPT : Piperacillin / Tazobactam Tetra: Tetracycline SUT: sulfatrimethropim

The three collection points presented high levels of resistance. However, Point 3 presented the highest occurrence with $45 \%$; Point 2 detection was $25 \%$ and Point 1 was $30 \%$. The lower percentage found in the second collection point may be due to the renovation that was being carried out in the second ICU of the General Hospital of Roraima, which possibly caused a smaller number of isolated microorganisms.

The sensitivity to non-Beta-lactamic antimicrobials in effluent can be observed in the evaluation study of the resistance to antibiotics in bacteria isolated from hospital effluent in a university hospital of Maringá conducted by Abreu et al. (2009), in which 39 strains were isolated and identified, and among them 18 species showed resistance to antibiotics, with $82.1 \%$ being sensitive to ciprofloxacin and $71.8 \%$ to amikacin and gentamicin.

The authors of the previously mentioned research suggest in the final considerations the urgency of the implantation of an efficient treatment system of their effluents. Similar observation is found in the work carried out by Cavalcanti et al. (2011), which claims that by microbiologically characterizing the effluent of a hospital in Natal-RN, the treatment has the purpose of improving the life quality of the population and local public health due to the reduction of the launching of multi-resistant strains in the receiving water resources. In a diagnosis regarding hospital sewage treatment in Brazil, Vecchia et al. (2009) found that only three hospitals in Brazil have some type of hospital sewage treatment, with these units located in the South and Southeast regions of Brazil.

\section{MoleCUlar DETECTION OF TEM, SHV AND CTX-M GENES}

Among the 10 strains isolated from the effluent and identified phenotypically, 8 showed positive amplification for the presence of beta-lactamase genes. Collection point 2 (Pc2) presented the lowest detection frequency ( 3 phenotypic findings and 1 strain with molecular identification). The amplification of the encoding genes among the ESBL-positive strains by PCR showed that 37.5\% (3) had the TEM gene, $12.5 \%$ (1) SHV, $12.5 \%$ (1) $12.5 \%$ simultaneously TEM+SHV (1) 12,5\% CTX + TEM and 25\% (2) obtained positive detection for the 3 genes simultaneously. The CTX-M gene was found only in association, and among them there was no detection of CTX + SHV (Table 3). 
Table 3 - Distribution in the strains of the encoding genes effluent of ESBL. By bacterial gender/species

\begin{tabular}{|c|c|c|c|c|c|c|c|c|}
\hline \multirow[b]{2}{*}{$\begin{array}{l}\text { Collect } \\
\text { Points }\end{array}$} & \multirow[b]{2}{*}{$\begin{array}{c}\mathrm{N}^{\circ} \text { of } \\
\text { Identified } \\
\text { Strains }\end{array}$} & \multicolumn{7}{|c|}{ Resistance genes found } \\
\hline & & TEM & CTX & SHV & $\begin{array}{l}\text { CTX + } \\
\text { SHV }\end{array}$ & $\begin{array}{l}\text { TEM } \\
+ \text { SHV }\end{array}$ & $\begin{array}{l}\text { CTX + } \\
\text { TEM }\end{array}$ & $\begin{array}{c}\text { CTX } \\
+ \\
\text { TEM } \\
+ \\
\text { SHV }\end{array}$ \\
\hline $\begin{array}{c}1 \\
\text { ICU } \\
1 \text { and } 2\end{array}$ & 3 & 1 & - & 1 & - & 1 & - & - \\
\hline $\begin{array}{c}2 \\
\text { ICU } 3\end{array}$ & 1 & - & - & - & - & - & - & 1 \\
\hline $\begin{array}{c}3 \\
\text { All the Blocks }\end{array}$ & 4 & 2 & - & - & - & - & 1 & 1 \\
\hline TOTAL & 8 & 3 & - & 1 & - & 1 & 1 & 2 \\
\hline
\end{tabular}

The obtained results in the amplification of the effluent genes were similar to the investigation of strains present in effluent and urinary infections carried out by Zarfel et al. (2013), which identified in four of the E. coli isolates positive ESBL (Three of sewage sludge and one of the ICU), three of them harbored the TEM gene, being considered the most prevalent in effluent samples.

When investigating bacterial diversity, antimicrobial resistance patterns and types of beta-lactamase genes in Gram-negative bacteria isolated from hospital effluent in Rio de Janeiro, Chagas et al. (2011) reported that the most common ESBL-producing isolates were strains of K. pneumoniae, E.cloacae and E. coli. TEM, SHV and CTX-M genes were detected in 82, 48 and $67 \%$ of bacterial isolates, respectively.

In a quantitative evaluation of the Escherichia coli that produces $\square$-lactamase of extended-spectrum in wastewater from a French university hospital compared to strains found in patients hospitalized in the same hospital unit, Drieux et al. (2016), through the genotyping process, by relating the subtypes of the CTX gene, the most prevalent in the research, found that the presence of ESBL-producing bacteria in patients can lead to a diffusion of this enzyme through the hospital effluent and ends up concluding that the health services play an important role in the dissemination of ESBL-producing strains by not treating their waste.

\section{CONCLUSIONS}

This study concluded that all septic tanks collected were positive for ESBL detection, and these detected bacteria were found to be resistant to almost all drugs tested, including the latest generation of drugs. The genes encoding the ESBL were found isolated and in association at all points analyzed with strains detected that presented similar profile to those identified in patients from hospital environments, suggesting their migration to the effluents, so the results indicated the wide dissemination of the genes of ESBL in the GHR effluent.

\section{REFERENCES}

ABREU, E.T. et al., Avaliação da resistência a antibióticos de bactérias isoladas de efluente hospitalar. Acta Scientiarum. Technology, v. 32, n. 1, p. 1-5, 2010. 
ANVISA - AGÊNCIA NACIONAL DE VIGILÂNCIA SANITÁRIA. Resolução RDC nº. 306/2004. Dispõe sobre o regulamento técnico para o gerenciamento de resíduos de serviço de saúde. Diário Oficial da União 10/12/2004.

ASSOCIAÇÃO BRASILEIRA DE NORMAS TÉCNICAS. NBR 9898: Preservação e técnicas de amostragem de efluentes líquidos e corpos receptores. Rio de Janeiro, 1987.

BRASIL. Agência Nacional de Vigilância Sanitária (ANVISA). Gerência de Investigação e Prevenção das Infecções e dos Eventos Adversos (Gipea) e Gerência Geral de Tecnologia em Serviços de Saúde (GGTES). Investigação e Controle de bactérias Multirresistentes. Brasília: ANVISA, 2007. 21 p. Disponível em: <http:// www.anvisa.gov.br/servicosaude/controle/reniss/manual\%20_controle_bacterias.pdf $>$. Acesso em: 15 maio 2015.

CANTÓN, R.; COQUE, T. M. The CTX-M $\beta$-lactamase pandemic. Current opinion in microbiology, v. 9, n. 5, p. 466-475, 2006.

CARMO, S.D et al, Detecção de Betalactamases de espectro estendido (ESBL) em isolados de escherichia coli uropatogênicas (UPECS) oriundos de pacientes da comunidade. Revista de Patologia Tropical, v.41, n.4, p.419-426, out.-dez. 2012.

CAVALCANTI, D. G. K. et al. Caracterização físico-química e microbiológica de efluente hospitalar na Região Metropolitana do Natal-RN-Brasil. Revista de Biologia e Ciências da Terra, v. 11, n. 1, p. 205-210, 2011.

CHAGAS T.P.G. et al, Multiresistance, beta-lactamase-encoding genes and bacterial diversity in hospital wastewater in Rio de Janeiro, Brazil J. Appl. Microbiol., v. 111 p. 572-581, 2011.

CHAPMAN, P. A. et al. Comparison of culture, PCR and immunoassays for detecting Escherichia coli O157 following enrichment culture and immunomagnetic separation performed on naturally contaminated raw meat products. International Journal of Food Microbiology, v. 68, n. 1, p. 11-20, ago. 2001.

CHATTERJEE, J.; RAI, N.; K SAR, S. A Study on the Wastewater Treatment from Antibiotic Production. Current World Environment, v. 9, n. 1, p. 223-226, 2014.

CLSI. Performance Standards for Antimicrobial Sucetibility Testing- Twenty Second Information Supplement. M100-S22. Clinical Laboratory and Standard Institute, v.32, n.3, Jan 2012.

D'ANDREA, M. M. et al. CTX-M-type $\beta$-lactamases: a successful story of antibiotic resistance. International Journal of Medical Microbiology, v. 303, n. 6, p. 305-317, 2013.

DRIEUX, L. et al. Quantitative evaluation of extended-spectrum $\beta$-lactamase-producing Escherichia coli strains in the wastewater of a French teaching hospital and relation to patient strain. Antimicrobial Resistance \& Infection Control, v. 5, n. 1, p. 1, 2016.

FERREIRA, C.M. et al. Extended-spectrum beta-lactamase-producing bacteria isolated from hematologic patients in Manaus, State of Amazonas, Brazil. Brazilian Journal of Microbiology, v. 42, n. 3, p. 1076-1084, 2011.

GULKOWSKA, A. et al. Removal of antibiotics from wastewater by sewage treatment facilities in Hong Kong and Shenzhen, China. Water research, v. 42, n. 1, p. 395-403, 2008.

GUSATTI C., et al, Resistência a $\beta$-lactâmicos em Acinetobacter spp isolados de efluente hospitalar no sul do Brasil. Rev. Soc. Bras. Med. Trop. v.42, n.2 Mar./Apr. 2009. 
HENDRICKS, R.; POOL, E.J. The effectiveness of sewage treatment processes to remove faecal pathogens and antibiotic residues. Journal of Environmental Science and Health, Part A, v. 47, n. 2, p. 289-297, 2012.

KORZENIWESKA E., HARNISZ. Beta-lactamase-producing Enterobacteriaceae in hospital effluents.. Journal of enviromental management, v. 123, p 1-7, july 2013.

LEISTNER, R. et al, Risk Factors Associated with the Community-Acquired Colonization of Extended-Spectrum Beta-Lactamase (ESBL) Positive Escherichia Coli.An Exploratory Case Control Study. PLOS ONE, v, 8, n. 9, sept 2013.

LIVERMORE, D.M. et, al. Are susceptibility tests enough, or should laboratories still seek ESBLs and carbapenemases directly? Antimicrob. Agents Chemother. Advanced Acess. March 2012. .

MUNIER, G.K, Positive Extended-Spectrum--Lactamase (ESBL) Screening Results May Be Due to AmpC-Lactamases More Often than to ESBL. Journal of Clinical Microbiology, v.48, n.2, p. 673-674, feb 2010.

NNADOZIE, C. F.; KUMARI, S.; BUX, F. Status of pathogens, antibiotic resistance genes and antibiotic residues in wastewater treatment systems. Reviews in Environmental Science and Bio/Technology, v. 16, n. 3, p. 491-515, 2017.

OVERDEVEST, I. Extended-Spectrum $\beta$-Lactamase Genes of Escherichia coli in Chicken Meat and Humans, the Netherlands. Emerging Infectious Diseases, v. 17, n.7, p.1216-1222, July 2011.

PATTARACHAI et al. Molecular Characterization and Epidemiology of Extended-Spectrum--Lactamase-Producing Escherichia coli and Klebsiella pneumonia Isolates Causing Health Care-Associated Infection in Thailand, Where the CTX-M Family Is Endemic. Antimicrobial Agents and Chemoterapy, v. 5, n.8, p-28182824, 2008.

PRADO, T., et al., Detection of extended-spectrum b-lactamase-producing Klebsiella pneumoniae in effluents and sludge of a hospital sewage treatment plant. Letters in Applied Microbiology, v 46, p 136-141, 2008.

REINTHALER, F.F, et al. ESBL-producing E. coli in Austrian sewage sludge. Water Research, v. 44, p. 19811985, March 2010.

RORAIMA. Plano de Gerenciamento de Resíduos de Serviços de Saúde - PGRSS. Secretaria de Estado da Saúde. Hospital Geral de Roraima, 48p, Roraima, 2013.

SILVA, D.G.K.C; et al. Caracterização físico-química e microbiológica de efluente hospitalar na Região Metropolitana de Natal-RN - Brasil. Revista de Biologia e Ciências da Terra, v. 11, n. 1,p 205-210, 2011.

SILVA, K. C.; LINCOPAN, N. Epidemiologia das betalactamases de espectro estendido no Brasil: impacto clínico e implicações para o agronegócio. J. bras. patol. med. lab, v. 48, p. 91-99, 2012.TACÃO, M. et al. Co-resistance to different classes of antibiotics among ESBL-producers from aquatic systems, Water Research, v. 48, p-100-107, 2014.

VECCHIA, A. D. et al. Diagnóstico sobre a situação do tratamento do esgoto hospitalar no Brasil. Rev Saúde Ambiente, v. 10, p. 65-69, 2009.

WANI, K. A. et al. Extended Spectrum-Lactamase Mediated Resistance in Escherichia Coli in a Tertiary Care. International journal of health sciences, v. 3, n. 2, 2010.

WATKINSON, A. J.; MURBY, E. J.; COSTANZO, S. D. Removal of antibiotics in conventional and advanced wastewater treatment: implications for environmental discharge and wastewater recycling. Water research, v. 41, n. 18, p. 4164-4176, 2007. 
ZARFEL G. et al, Comparison of extended-spectrum- $\beta$-lactamase (ESBL) carrying Escherichia coli from sewage sludge and human urinary tract infection. Environmental Pollution, v. 137, p; 192-199, Feb 2013. 